\title{
A Brief Comment on Communicative Language Teaching
}

\author{
Fang Yuan \\ Huaiyin Normal University, Jiangsu, China \\ Email: irisandy@163.com
}

\begin{abstract}
Communicative Language Teaching (CLT) is more and more popular and becoming the mainstream in the second language teaching classroom. It reviews its development and explores the use in china all around. Via analyzing some hidden problems in second language classroom, some suggestions are promoted.
\end{abstract}

Index Terms - audio-lingual method, CLT, character, problems, second language classroom

\section{THEORETICAL FOUNDATION AND BACKGROUND}

Influenced by the nature of language and language learning, many approaches and methods in language teaching are constantly changing corresponding to the need of era, all of which contribute a lot in the history of mankind, such as the Translation Method, the Situational Language Teaching, the Audio-lingual Method, the Communicative Language Teaching, and other approaches although with less influence which can also give us much inspiration. All of them were once quite the rage, but till now, the Communicative Language Teaching (CLT) is more and more popular and becoming the mainstream in the second language teaching classroom. It spreads widely and constantly develops.

CLT can be dated from the 1960s. At that time, much more communication was required in the European continent among the countries, and the formation of International Association of Applied Linguistics was also promoted. Under these circumstances, the Communicative Method emerged and was quickly welcomed. Besides these, at that time, the notional syllabus published in 1976 which was proposed by D. A. Wilkins had a significant impact on the development of CLT. Currently, CLT is also greatly accepted and encouraged in Chinese second language classroom, which actives the class and gain great harvest in a communicative way whereas still some new problems come along.

\section{SOME INTRODUCTIONS ABOUT CLT}

CLT has two main theoretical foundations: 1) the theory of language, including British applied linguistics, British functional linguistics and American work in sociolinguistics; 2) the theory of language learning, actually, there isn't any explicit discussion on learning theory, however, three principles might be described here: i. Communicative Principle; ii. Task Principle; iii. Meaningfulness Principle.

\section{A. Syllabus}

After one of the first syllabus models to be proposed we mentioned before — notional syllabus, till now, CLT does not have a unified syllabus. Different scholars put forward different models. Yalden (1983) listed eight types: 1) structures plus functions (Wilkins 1976); 2) functional spiral around a structural core (Brumfit 1980); 3) structural, functional, instrumental (Allen 1980); 4) functional (Jupp and Hodlin 1975); 5) notional (Wilkins 1976); 6) interactional (Widdowson 1979); 7) task-based (Prabhu 1983); 8) learner generated (Candlin 1976, Henner-Stanchina and Riley 1978). Types1-5 can be ascribed to the proto-syllabus, and a current interest concentrates on the designs of types6-8. But the discussion around syllabus models continues in the CLT literature and it is hard to come to an agreement.

\section{B. Main Character}

i. Focus on communicative and contextual factors. CLT pursues authentic communication in life and content-oriented, meaning negotiation is its main purpose.

ii. Involve with learner-centered and experience-based. Different from the traditional teacher-centered class, CLT encourages students learn actively and independently, cultivating their communicative competence.

\section{The Understanding of Communicative Competence}

In Hyme's view, a person who acquires communicative competence acquires both knowledge and ability for language.

In his book Teaching Language as Communication (1978), Widdowson focused on the communicative acts underlying the ability to use language for different purposes.

Canale and Swain (1980) identified four dimensions of communicative competence: grammatical competence, which domains grammatical and lexical capacity; Sociolinguistic competence, an understanding of the social context in which 
communication takes places; Discourse competence, the interpretation of individual message elements in terms of their interconnectedness and of how meaning is represented in relationship to the entire discourse or text; Strategic competence, the coping strategies that communicators employ to initiate, terminate, maintain, repair, and redirect communication. And this identification has been widely accepted.

Some scholars believe that the communicative competence combines two kinds of knowledge: the language knowledge and the non-language knowledge, while the latter consists of context knowledge, world knowledge and cross-culture knowledge.

Communicative Competence refers to the ability to use language (oral or written form) and sub-language (body language) to achieve some communicative purpose, including both comprehension and expression. That is to say, the cultivation of students' communicative competence means cultivating all the four skills-listening, speaking, reading and writing. (Dingfang Shu, Zhixiang Zhuang 2008)

\section{CLT IN CHINA}

\section{A. The Concept of "Strong" Version and "Weak" Version of CLT}

Howatt once distinguished between a "strong" and a "weak" version of CLT: The weak version stresses the importance of providing learners with opportunities to use their English for communicative purpose and attempts to integrate such activates into a wider program of language teaching, that's "learning to use English". The strong version claims that language is acquired through communication, that's "using English to learn it".

\section{B. The Use of CLT in China}

In China, in most second language classrooms, teachers take the former version, which is the weak one. Besides the basic principle of communication, the weak version regards that the grammatical structure cannot be omitted in the use of foreign language. Grammar teaching helps the students to form the ability to participate in the real social communication. Nowadays, most textbooks used in our primary school and middle school can embody the use of the principle of Communicative Method; they are compiled on the structural-notional, functional syllabus. We can find that in these textbooks, no matter the vocabulary, dialogue or reading material are all related to the students' real life, but grammatical language points are also explained and arranged in a logical sequence. We are delightful to see the advancement we have made in English teaching in recent years, more and more people study English actively, students can speak freely when meet with a foreigner etc... In a whole, English teaching in China is moving forward, but if we get down to thinks over, there are also some severe problems facing us. For example, students in primary school can act actively in class, but more and more silent with them growing. Some people even doubt that if it is necessary to teach everyone English and make English learning so permeated. Of course, there are various reasons from the teachers, students, even the whole society. So the major problem in China concentrates not on whether to teach, but how to teach. How to cultivate the students' learning ability? Maybe it is a huge project we have to endeavor together. Besides that, CLT applies more in middle school in China, but less application can be found in college. Wang Zongyan once conducted a research on the use of CLT in Shanghai Foreign Language University and Zhejiang University separately, and the result is much delightful, which can give us much inspiration in the future research.

\section{MY VIEWS ON CLT}

Distinguishing features between the Audio-lingual Method and the CLT, some of the main characters of CLT are quite acceptable.

i. Contextualization is a basic premise and authentic material will be sought. Under this circumstance, the teaching content and teaching activities will closely link with students' own experience, which can be helpful to reduce students' attitudes of being boring, more attention will be focused and long-time memory can also be enhanced.

ii. Sequencing is determined by any consideration of content, function, or meaning which maintains interest. To this point, teachers can arrange their teaching sequence according to their teaching needs and students' response. Besides the sequence, the quantity and quality of different teaching content can also be added or lessened if necessary. All these acquire teachers' observation to the whole class, especially the after-class reflection. That's to say, instead of following the text blindly, teachers should use the teaching material flexibly.

However, with the wide spreading of CLT, problems occur one by one in the teaching classroom, and also some disputes come along.

i. CLT emphasizes learner-centered teaching process and more communication is promoted, which may cause two problems. On the one hand, CLT over stresses the function and meaningfulness of language on the largest scale, meaning is the major object, but it excludes the role played by grammar teaching and ignores the entity of the language system. On the other hand, how to operate these principles effectively is still a problem hard to solve and have some distance with the ideal state. To the first aspect, Michael H. Long gave us a new concept called "Focus on Form" in his article named "Focus on form in Task-Based Language Teaching", which can be helpful to solve this problem. "Focus on form...overtly draw s students' attention to linguistic elements as they arise incidentally in lessons whose overriding focus is on meaning or communication. (Long, 1991: 45 46) 
ii. Not less people mistake that CLT applies only to the listening-speaking class, and when we talk about the ability of communication, people usually emphasize more on the oral aspect, which brings two limitations: 1) the ignorance of the research on written communication; 2) the ignorance of the research on the comprehensible ability. Let's look at the first phenomenon; first, we should make clear that the communicative competence we have mentioned include all the four skills including listening, speaking, reading and writing. In a traditional reading class, "bottom-up approach" is usually adopted. Under this model, students usually ignore the understanding of language meaning and the authors' communicative intention. Of course, Ferdiand de sausure distinguished the difference between langue and parole, here we talk about the language meaning in a broad sense, including the lexical meaning, grammatical meaning, figurative meaning, collocative meaning, modal meaning and the meaning in a language system, especially in the whole context. So, some problems occur, students take the word and structure isolated, the thinking pattern and the reading ability are held back. So, more meaningful communication should also be encouraged when we deal with the reading material, such as the communication between students and the reading material, the communication between students and the author, the communication between students and students, and the communication between students and teacher etc.. The second refers to the comprehensible ability; actually, this aspect is quite important. Krashen's Input Hypothesis emphasizes the importance of comprehensible input. To solve this problem, on the one hand, teacher can help students to form much standard target language; students can also gain input through all round both in and out of the classroom. On the other hand, students can use self-linguistic-feeling to monitor themselves.

iii. In CLT, comprehensible pronunciation is sought. Fluency is more important than accuracy. Compared with CLT, Audio-lingual Method sets great store on the students' pronunciation. Which is reasonable? Different people hold different views. According to Vivian Cook: "Training students to speak swiftly and accurately may have helpful side effects on their working memory and hence on their general ability to process language." In fact, the neglect of pronunciation in recent years has occurred and becomes worse and worse; teachers give less attention to students' pronunciation, even to the beginners. However, the obstruction caused by inaccurate pronunciation can also influence students' listening more or less. In fact, we put the fluency on the first place, which doesn't mean that teachers can neglect the mistakes students made no matter in pronunciation or grammar or expression. So I hold the view from Cook and I think we should pay more attention to pronunciation and take it seriously, especially in our middle school.

\section{CONCLUSION}

At last, I'd like to quote the four requirements put forward by D.Brown applied in the Communicative Teaching Classroom, and I hope our teachers can get some inspiration and know better about CLT.

i. The purpose of classroom learning completely concentrates on the parts constituted by communicative competence, not limiting to the grammar or language ability.

ii. It is the function not the form to organize or arrange the sequence of the class. The mastery of the form is achieved through the embodiment of function.

iii. Fluency is more important to accuracy. The final purpose of CLT is to make your statement expressive and acceptable.

iv. In a communicative class, students were encouraged to use language creatively in almost real context.

Till now, CLT has been constantly improving and become a much advanced teaching method. But After all, to my view, different teaching objects, different teaching aims, different teaching content and different teaching condition acquire different teaching methods; we should flexibly use these methods.

\section{REFERENCES}

[1] Brown, H.D. (1978). Principles of Language Learning and Teaching. (2nd edition) Eaglewood Cliffe, New Jersey.

[2] Brown, J.D. (1981).William Littleword (ed.).Communicative Language Teaching: understanding Research in Second Language Learning. Cambridge University Press.

[3] Brumfit, J. (1980). Problems and Principles in English Teaching. Principles Institute of English.

[4] Canale, M. \& Swain, M. (1980). Theoretical Bases of Communicative Approaches to Second Language Teaching and Testing. Applied Linguistics 1, 1-47.

[5] Cook Vivian. (2000). Linguistics and Second Language Acquisition. Foreign Language Teaching and Research Press.

[6] Cook Vivian. (2000). Second Language Learning and Language Teaching. Foreign Language Teaching and Research Press.

[7] Hu, Jianming. (2002). Communicative Language Teaching and English Teaching in China. Guangdong Education Press.

[8] Long, M. H. (1997). Focus on form in Task-Based Language Teaching. University of Hawaii.

[9] Richards, J. C \& Rodgers, T. S. (2005). Approaches and Methods in Language Teaching. Combridge University Press.

[10] Sausure, F. de. (2007). Course in General Linguistics. Jiuzhou Press.

[11] Shu, Dingfang \& Zhuang, Zhixiang. (2008). Modern Foreign Teaching-Theory, Practice and Method. Shanghai Foreign Language Education Press.

[12] Wang, Linhai. (2007). The Analysis towards CLT Theory and Practice. Language Learning. No.4

[13] Widdowson, H. J. (1978). Teaching Language as Communication. Oxford University Press.

[14] Wilkins, D. (1976). Notional Syllabuses: A Taxonomy and its Relevance to Foreign Language Curriculum Development. London: Oxford University Press.

[15] Yalden, J. (1983). The Communicative Syllabus: Evolution, Design, and Implementation. Oxford: Pergamon. 
Fang Yuan was born in Huai'an, China in 1983. She received her B. degree from Huaiyin Normal University, China in 2005, and now is pursuing her M.A. degree in linguistics in Nanjing Normal University, China.

She is currently an assistant professor in the School of Foreign Languages, Huaiyin Normal University, Huai'an, China. Her research interests include psycholinguistics, cognitive linguistics and its practice in Second Language Teaching. 